Jane Lung*

School of Business

Macao Polytechnic Institute, Macao SAR, China

wylung@ipm.edu.mo

\title{
THE DISCURSIVE HIERARCHICAL PATTERNING IN ACCOUNTING CASES
}

\section{Abstract}

This study examines the genre of accounting cases in academic contexts. It is an attempt to extend Lung's (2008) model of discursive hierarchical patterning of case analysis to a study of accounting cases and to propose a model of discursive hierarchical patterning of cases in Accounting. It examines (1) the kind of information the generic moves in accounting cases call for; (2) how these moves are embedded in a discursive pattern; and (3) how these individual discursive patterns are organized in a hierarchy and how this discursive hierarchical patterning can be explained by the essential nature inherent in Accounting. The study examines a corpus of 150 accounting cases with the focus on uncovering the patterns of discourse construction. The implication of the study is there is a need to make the knowledge of accounting discourse more explicit, helping students recognize that there is such information as discursive hierarchical patterning on a cognitive level. To raise students' awareness, this paper suggests using direct teaching by adopting the model of discursive hierarchical patterning of accounting cases (Accounting DHP) to teach the characteristics of accounting discourse. This, in turn, may help students transform disciplinary knowledge and discourse conventions into meaningful dialogues with the evolving knowledge in the discipline.

\section{Key words}

discursive hierarchical patterning (DHP), genre analysis, generic moves, case analysis, Accounting.

\footnotetext{
* Corresponding address: Jane Lung, School of Business, Macao Polytechnic Institute, Rua de Luis Gonzaga Gomes, Macao, SAR, China.
} 
Sažetak

Ova studija istražuje žanr slučajeva u oblasti računovodstva u akademskim kontekstima i predstavlja pokušaj da se model obrazaca diskurzivne hijerarhije Lungove (2008) u analizi slučajeva primeni na analizu slučajeva iz računovodstva i da se predloži model obrasca diskurzivne hijerarhije u ovoj oblasti. Istražujemo (1) vrstu informacija koju iziskuju žanrovske etape $u$ slučajevima u oblasti računovodstva; (2) kako se te etape ugrađuju u diskurzivne obrasce; i (3) kako se pojedinačni diskurzivni obrasci organizuju u hijerarhiju i kako se dobijeni obrasci mogu objasniti samom prirodom računovodstva. Analiza uključuje 150 slučajeva sa ciljem da se otkriju obrasci konstrukcije diskursa. Rezultati ukazuju na potrebu da se znanje o diskursu računovodstva studentima predstavi na eksplicitniji način, što će im pomoći da uoče postojanje obrasca diskurzivne hijerarhije na kognitivnom nivou. U cilju podizanja svesti studenata u radu se predlaže korišćenje direktnog obučavanja kroz usvajanje modela obrazaca diskurzivne hijerarhije u oblasti računovodstva pri učenju osobina diskursa računovodstva. Ovo će, zauzvrat, pomoći studentima da znanje i konvencije discipline usklade sa daljim razvojem saznanja u ovoj oblasti.

\section{Ključne reči}

obrasci diskurzivne hijerarhije, analiza žanra, žanrovske etape, analiza slučajeva, računovodstvo.

\section{INTRODUCTION}

While previous studies have investigated many aspects of genre and the research on genres in specific disciplines have focused on rhetorical move-structures (Bhatia, 1993, 1999, 2004; Holmes, 1997; Lung, 2008; Swales, 1990), this paper attempts to go one step further and consolidate much of the earlier work by examining the genre of accounting cases in academic contexts. It extends Lung's (2008) model of a discursive patterning of case analysis to a study of accounting cases and proposes a model of discursive hierarchical patterning (DHP) of cases in Accounting. The focus of this paper is to examine (1) the kind of information the generic moves in accounting cases call for; (2) how these moves are embedded in a discursive pattern; and (3) how these individual discursive patterns are organized in a hierarchy and how this discursive hierarchical patterning can be explained by the essential nature inherent in Accounting.

In the field of English for Specific Purposes (ESP), genre analysis has received considerable attention, and the understanding of the relationship between 
communicative purposes and linguistic patterns of the genre has been a key area of genre research (Bhatia, 1993; Swales, 1990). Both English for Academic Purposes (EAP) and ESP researchers and practitioners have been studying the genres associated with academic discourse to demonstrate the strong disciplinary boundaries across the disciplines (Bhatia, 1999; Bhatia, Langton \& Lung, 2004; Candlin \& Hyland, 2000; Flowerdew \& Peacock, 2001; Hyland, 2000; Lung, 2011; Paltridge, 2001). Recent research focusing on multi-dimensional and multiperspective analyses of professional and institutional genres has resulted in examining why professionals use language the way they do and how disciplinary variation and conflicts arise (Bhatia, 2004, 2016; Lung, 2014, 2017).

Genre analysis has been widely used in both academic and professional settings. In academic settings, for instance, Bitchener (2010), Gil-Salom and SolerMonreal (2014) and Kwan, Chan, and Lam (2012) look into linguistic and discursive features in literature reviews from different perspectives. While Fryer (2012) and Hao (2015) examine the genre of medical and biology research articles, Behnam and Nikoukhesal (2017) compare the move structure of physical and social sciences research article introductions. In professional settings, for instance, while Bhatia and Lung (2012) explore the structure and discursive organisation of arbitration awards, Atkins and Harvey (2010) discuss the discursive patterns in young people's email in the field of health communication, and Lung (2014) examines the needs of hoteliers in the workplace. Bhatia, Jones, Bremner, and Peirson-Smith (2013) and Lung (2017) look at interdiscursivity in public relations (PR) involving professional communication and how this in turn results in greater understanding of the changing workplace environment of the PR profession and helps individual PR practitioners cope with the challenges they face.

Extensive research has been done on examining language learning and teaching in ESP and EAP, and genre analysis has proved to be pedagogically efficient in making students aware of the genre conventions such as rhetorical organization and linguistic features of the genre under study. Genre-based teaching (Hyland, 2007; Swales, 2004) examines text as discourse, or "the way we use language to communicate, to achieve purposes in particular situations" (Hyland, 2008: 93). Hyland (2009: 7) further asserts that "disciplinary variation [...] underlies most specificity" in academic discursive practices. Tardy (2011) points out that genre pedagogies help teachers provide targeted instructions to meet the language and writing needs of students. Lee (2012: 120) maintains that "genre is a promising tool to sensitise L2 learners to the purpose, audience and context of writing and help them understand how the structural and language features of written texts can contribute to meaning making".

In view of the previous research, this paper examines the genre of accounting cases in academic contexts and proposes a model of discursive hierarchical patterning of cases in Accounting. A case in Accounting is an illustration of how accounting principles relate to the real world, and is an analysis of business accounting problems. Below are some definitions of cases in Accounting: 
1. "A case is sort of assistance for students to bridge the gap between their academic training and the 'real world' of accounting. It provides a basis for the development of life-long learning skills." (McQuade, 1993: ix).

2. "A case is an analysis of a problem, by thinking and discussing about a problem [sic]; students can acquire skills [sic] in management use of accounting information." (Anthony, Reece, \& Hertenstein, 1994: vii).

These definitions lay the groundwork for the following discussion of the discursive hierarchical patterning of accounting cases as well as the specific language and presentation needed for Accounting.

A discursive hierarchical pattern is a model proposed to describe how individual discursive patterns are organized in a hierarchy. An individual discursive pattern is considered to consist of textual aspects, generic aspects, and social aspects (Lung, 2008). Textual aspects involve the use of linguistic resources such as lexico-grammar and discourse markers. Generic aspects relate to the choice of generic moves. Although this is quite a narrow view of genre, it shows how communicative purposes are realized in the moves and how these moves are placed within a pattern. Social aspects refer to how language is used sociocritically, showing how one's identity is projected and interpreted within the disciplines. Generic moves refer to the building blocks in a discursive pattern. Each generic move has its characteristic thematic selection and linguistic choices to achieve the communicative purposes of the move.

\section{DATA COLLECTION AND METHOD}

This study examined 150 accounting cases (146,404 words) obtained from individual commercial textbooks ${ }^{1}$ and in-house materials developed by instructors or professors teaching Accounting. Specifically, these were gathered from both professors and students from the five main universities in Hong Kong, involving some 40 professors who used these cases when conducting their undergraduate and postgraduate programs in Hong Kong. Thus, the corpus is considered to be representative of the cases used in teaching Accounting. The accounting cases collected for the research focused on applying accounting concepts and principles to the analysis of business transactions when describing an organization's financial position.

\footnotetext{
${ }^{1} \mathrm{~A}$ list of these textbooks is provided in the Appendix.
} 


\section{MODEL OF TYPICAL DISCURSIVE HIERARCHICAL PATTERNING OF CASES}

Lung (2008) proposes a typical discursive hierarchical patterning of cases in general as shown in Figure 1, which consists of five individual patterns (DHP 1-5).

\begin{tabular}{|c|c|}
\hline $\begin{array}{l}\text { DHP-1 } \\
\text { Ac }\end{array}$ & $\begin{array}{l}\text { Opening Paragraph and/or Background Information } \\
\text { Specific Area of Interest/Context } \\
\text {, Economics, Law, Management, Finance, Operations, Others }\end{array}$ \\
\hline DHP-2 & $\begin{array}{c}\text { Specific Problem and/or Specific Situation } \\
\text { Identifying the Issue }\end{array}$ \\
\hline DHP-3 & Data Presentation \\
\hline DHP-4 & $\begin{array}{c}\text { Data Process } \\
\text { Assessing Information } \\
\text { Application of Concepts/Theories/Principles } \\
\text { Making Assumptions }\end{array}$ \\
\hline DHP-5 & $\begin{array}{c}\text { Closing } \\
\text { Summing up/Giving Advice/Alternatives, etc. }\end{array}$ \\
\hline
\end{tabular}

Figure 1. Model of typical discursive hierarchical patterning of cases (Lung, 2008)

From the preceding model, it can be seen that in order to provide the reader with the proper context, DHP-1 must open the case, including information about the institution, time, place, and people involved. Next, the specific problems and issues involved are dealt with under the heading DHP-2 (Specific Problem and/or Specific Situation). This outlines what somebody should have done or should do, as well as who or what is to blame for the situation. This leads to presenting the data of the case - DHP-3 (Data Presentation) followed by DHP-4 (Data Process). Finally, DHP5 (Closing) is used to close the case. 


\section{DISCURSIVE HIERARCHICAL PATTERNING IN ACCOUNTING}

The previous section presented a general model for discursive hierarchical patterning of cases. This section involves a discussion of the discursive hierarchical patterning of the 150 accounting cases used in this study. Figure 2 shows the overall discursive hierarchical patterns of the 150 accounting cases.

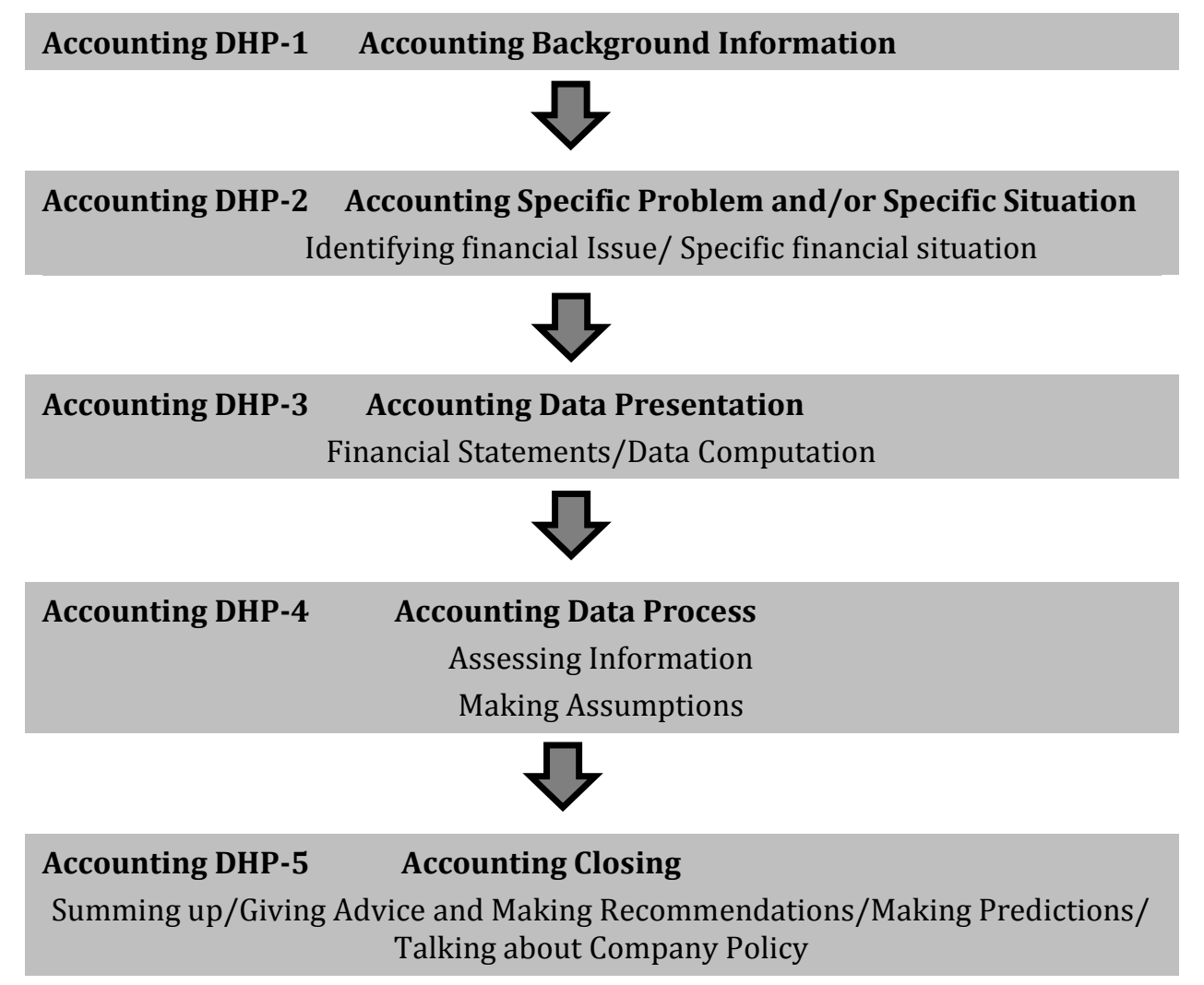

Figure 2. Discursive hierarchical patterning of accounting cases

On the surface, the discursive hierarchical patterning of accounting cases conforms to the typical hierarchical patterning of a case (Figure 1). However, the discursive hierarchical patterning in accounting cases involves specific information about the discipline. This kind of specific information will be discussed in the following sections.

As shown in Figure 2, Accounting DHP-1 (Accounting Background Information) provides a type of background information or specific area of interest related to a specific company. Accounting DHP-2 (Accounting Specific Problem and/or Specific Situation) discusses the specific problems or situations by identifying the issues involved leading to Accounting DHP-3 (Accounting Data Presentation) and Accounting DHP-4 (Accounting Data Process). Finally, Accounting 
DHP-5 (Accounting Closing) takes the form of summing up, making predictions, giving advice and making recommendations, as well as talking about the company policy.

All the 150 accounting cases contain Accounting DHP-1, DHP-2, DHP-3, DHP4 , and DHP-5. Table 1 shows the percentages of discursive hierarchical patterns found in the data. In terms of the contents of the 150 accounting cases, Accounting DHP-1 (Accounting Background Information) accounts for 34\%; Accounting DHP-2 (Specific Problem and/or Specific Situation) 8\%; Accounting DHP-3 (Data Presentation) 33\%; Accounting DHP-4 (Data Process) 23\%, and Accounting DHP-5 (Closing) 2\%.

\begin{tabular}{|l|l|c|}
\hline \multicolumn{2}{|l|}{ Accounting DiscurSIVE HiERARCHICAL PATTERNING (DHP) } & $\%$ \\
\hline Accounting DHP-1: & Accounting Background Information & 34 \\
\hline Accounting DHP-2: & $\begin{array}{l}\text { Accounting Specific Problem and/or Specific Situation } \\
\text { (Identifying financial Issue/ Specific financial situation) }\end{array}$ & 8 \\
\hline Accounting DHP-3: & $\begin{array}{l}\text { Accounting Data Presentation (Financial Statements / Data } \\
\text { Computation) }\end{array}$ & 33 \\
\hline Accounting DHP-4: & $\begin{array}{l}\text { Accounting Data Process (Assessing Information / Making } \\
\text { Assumptions) }\end{array}$ & 23 \\
\hline Accounting DHP-5: & $\begin{array}{l}\text { Accounting Closing (Summing Up / Giving Advice and Making } \\
\text { Recommendations / Making Predictions / Talking about } \\
\text { Company Policy) }\end{array}$ & 2 \\
\hline Total & & $\mathbf{1 0 0}$ \\
\hline
\end{tabular}

Table 1. Discursive hierarchical patterns found in accounting cases

The following section investigates, in detail, the discursive hierarchical patterning in accounting cases, and includes my own underlining emphasis in order to highlight the specific features of these individual patterns.

\subsection{Accounting DHP-1: Accounting background information}

Accounting DHP-1 (Accounting Background Information) provides the context for the cases and gives background information about the cases. The communicative purpose here is to set the scene and to prepare the reader for the case. The information given focuses on essential background information of a specific company, such as the company's financial stability and possible accounting problems.

In total, Accounting DHP-1 (Background Information) represents 34\% of the contents of the corpus (see Table 1). Since background information is more 
frequent in Accounting DHP-1 than the other patterns, I have looked into this pattern on a micro-level. As shown in Table 2, this pattern comprises four generic moves. These moves are Background Information about Institutions; Background Information about Countries; Background Information about People; and Background Information about Time, and their percentages in Accounting DHP-1 are $13 \%, 2 \%, 50 \%$, and 35\%, respectively. These moves do not follow a particular sequence.

\begin{tabular}{|l|l|c|}
\hline \multicolumn{2}{|l|}{ AcCounting DHP-1: Accounting BACKGROUND INFORMATION } & $\%$ \\
\hline Move 1 & Background Information about Institutions & 13 \\
\hline Move 2 & Background Information about People & 50 \\
\hline Move 3 & Background Information about Time & 35 \\
\hline Move 4 & Background Information about Countries & 2 \\
\hline Total & $\mathbf{1 0 0}$ \\
\hline
\end{tabular}

Table 2. Generic moves found in Accounting DHP-1

\subsubsection{Background information about institutions and people}

The results indicate that when it comes to background information, accounting refers more to people (50\%) than to time (35\%), institutions (13\%), and countries (2\%). Accounting professionals focus on meeting the specific needs of the business concerned (Batty, 1986). In addition, accounting involves the collection and recording of information in a manner most suitable for assisting management in its work. Its purpose is to help formulate overall strategies and long-range plans, new product development, and areas for investment. Accounting also provides information in regard to the allocation of resources, and frequently involves reports (Horgren, Foster, \& Datar, 1997). However, all these factors can differ from company to company. Thus, background information about the specific company, people involved, and the exact time of the financial periods are crucial in accounting.

Specific to this research, background information about the institution includes the name of the company (e.g. Empire Glass Company), the structure (e.g. major divisions each headed by a vice president), the name of the company's executive vice president (e.g. Landon McGregory), and products (e.g. manufacturing and selling glass food and beverage bottles).

People involved in the cases include the founder (e.g. Richard Hanson, founder of Hanson Manufacturing Company), the president (e.g. Jack Schwartz, president of Montrose Manufacturing Inc.), the chairman (e.g. the chairman of London Brick Ltd., Mr Jeremy Rowe), vice president (e.g. Suzanne Leister, marketing vice president of Baldwin Bicycle Company), general manager (e.g. Lou Debbink, 
general manager of the Warehouse Sales Division of American Steel Corporation), treasurer (e.g. Richard Berks, treasurer of Reading Manufacturing Company), partners of the company (e.g. Dave Lundberg and Adam Dixon, partners in the Dallas Consulting Group), the chief accountant (e.g. Brooks Coleman of Forner Carpet Company). It is important to give specific information about people, such as their full names and titles because these people are the company decision-makers - those who eventually made the financial decisions. For example,

\begin{abstract}
Empire Glass Company was a publicly held container and packaging company. It was organized into several major product divisions, each headed by a vice president who reported to the company's executive vice president, Landon McGregory. The Glass Products Division, the focus of this case, was responsible for manufacturing and selling glass food and beverage bottles...McGregory's corporate staff included three financial department heads - the controller, chief accountant, and treasurer. The controller's department consisted of only two people - 」ames Walker and his assistant, Ellen Newell. The market research and labor relations departments also reported in a staff capacity to McGregory. (Hawkins, 2003:1)
\end{abstract}

\title{
4.1.2. Background information about time
}

As for the presentation of time in the background information, it would appear that accounting gives the exact months and years. It is presented this way so that the case opens on a note of anticipation and suspense, setting up a structure in which something can take place over a period of time. In addition, it provides context by focusing on one single incident of the central character's life. For instance, Early in 1980, the marketing director and the finance director of Lille Tissages, S.A. met to prepare a joint pricing recommendation for Item 345.; In April 1983, John Harden felt that the company he had formed 12 years previously was at a critical point in its dependence.; In May 1989, Suzanne Leister, marketing vice president of Baldwin Bicycle Company, was mulling over the discussion she had the previous day with Karl Knott, a buyer from Hi-Valu Stores, Inc.

\subsection{Accounting DHP-2: Accounting specific problem and/or specific situation}

A common feature in the case analysis is to identify the problem or issue. Identifying problems and issues appears in all the accounting cases. In total, Accounting DHP-2 (Accounting Specific Problem and/or Specific Situation) takes up $8 \%$ of the contents of the corpus as shown in Table 1. Accounting DHP-2 identifies financial issues involved, and looks at a specific problem or situation facing a company. This is one of the crucial discursive patterns in accounting cases that could involve the financial situation or difficulties of the company. This 
includes operating losses and poor financial management, financial/expenditure budget control, achieving budgeted goals, incentive compensation plan, and profit margins. Accounting cases use expressions such as he was concerned about, he felt that it was important for him, she was rather anxious, and he feared in order to indicate that it is a pressing issue. In addition, there is a sense of urgency to the expressions; that the situations require immediate attention, and if it is not dealt with quickly, it will have immediate consequences. For example, He feared a further volume decline if it did not meet the competitive price. A narrative is given leading to the issues involved. Accounting is explicit in its ability to identify and locate the issue/problem. For example,

Frank Delaney owned and operated Delaney Motors, a General Motors automobile dealership in Ohio. Its operations consisted of new-car sales, used-car sales, parts sales, vehicle lease and rentals, vehicle service, and automobile body repairing and repainting. The dealership was profitable, earning almost 5 percent on sales, but the reported profit on the body shop operation seemed low to Mr. Delaney.

Consequently, he engaged a consultant to study the body shop operation and make recommendations. (Anthony, Hawkins \& Merchant, 2011:508)

The example takes the form of a narrative and points out the problem directly. In this case, the reported profit seemed low to the owner of the company. If the profit is low, then the possibility of engaging a consultant might be necessary. The example uses past tense to indicate that the situations/problems were a part of a sequence of completed past actions, which are facts.

The problems in accounting cases involve human participants, and Accounting provides a detailed description of the problem by using personnel names and personal pronouns. For instance,

Dale Walsh, the general manager had suspected for some time that the firm might save money and get equally good service by buying its containers from an outside source. After careful inquiries, he approached a firm specializing in container production, Packages, Ltd., and asked for a quotation. At the same time he asked Paul Dyer, his chief accountant, to give him an up-to-date statement of the cost of operating the container department. (Patel Bhavesh, 2001:261)

In this example, not only are personnel names used Dale Walsh, Paul Dyer, but also personal pronouns he, him, and his. In this way, it characterizes a specific real-life situation involving the interaction between the general manager, his chief accountant, and a firm. In addition, the example also takes the form of a narrative, showing that the functions of accounting are to supply information for decisionmaking. 


\subsection{Accounting DHP-3: Accounting data presentation}

After identifying issues, Accounting DHP-3 presents data in terms of Financial Statements/Data Computation. In total, Accounting DHP-3 (Accounting Data Presentation) takes up 33\% of the contents of the corpus as shown in Table 1. Data appear to be of almost equal importance in business disciplines. However, the way data are presented may be different in terms of the choice of presentation format and the method of phrasing its data. Findings in this study reveal that when presenting data, Accounting DHP-3 gives details of the financial situation of a company. It does so by providing the descriptions of the data and/or non-linear presentation of the data. As seen in Table 3, professionals present accounting data in three generic moves: General Descriptions of the Data; Financial Statements; and Figures/Graphs, and their percentages in Accounting DHP-3 (Accounting Data Presentation) are equal to $29 \%, 64 \%$, and $7 \%$, respectively.

\begin{tabular}{|l|l|c|}
\hline \multicolumn{2}{|c|}{ Accounting DHP- 3 (Accounting Data Presentation) } & $\%$ \\
\hline Move 1 & $\begin{array}{l}\text { General Descriptions of the Data } \\
\text { (Description of Budget Process / Profitability) }\end{array}$ \\
\hline Move 2 & Financial Statements / Data Computation & 64 \\
\hline Move 3 & Figures/Graphs & $\mathbf{1 0 0}$ \\
\hline Total & & 29 \\
\hline
\end{tabular}

Table 3. Generic moves found in Accounting DHP-3

All the financial activities are summarized in the Accounting Data Presentation (Accounting DHP-3). The summaries are within a specific period of time in terms of money transactions or events of a financial character, and financial statements. The communicative purpose of Accounting DHP-3 (Accounting Data Presentation) is to show the firm's financial position at a point in time, or the results of operating, financing, and investing activities. In addition, it explains the change in retained earnings from the beginning of the accounting period to the end of the period. The information described is then interpreted and manipulated into useful information. For instance, by using the information, monetary alternatives can be generated and compared, leading to a final selection.

Financial statements and data computation play a significant role $64 \%$ in Accounting DHP-3) as seen in Table 3. These statements include income statements, balance sheets, statement of cash flows, and statements of changes in equity. These financial statements are important, for instance, an income statement gives a picture of a company's revenues, expenses, gains, losses, net income, and earnings per share over a period of time. A balance sheet tells the 
company's financial position at a point in time, including its assets, liabilities, and equity. The statement of cash flows and the statement of changes in equity show how the financial situation changes over the period. Thus, this group of statements forms a complete set of financial statements. Specifically, they are structured representations of the financial performance and financial situation of a company. They also encapsulate the basic accounting principles and concepts, ${ }^{2}$ which are essential guidelines when recording and reporting accounting transactions.

Tabular form is used to format the balance sheet (see Figure 3). The header indicates the company ( $A B C$ Agency), the statement (Balance Sheet), and the period to which the statement relates (November 5, 2010). The balance sheet presents a company's financial situation at the end of a certain date, giving a "snapshot" of a company's financial situation at a point, indicating that all the transactions through that day (e.g. November 5, 2010) have been recorded. This follows the time period principle and continuity assumption of the accounting principles and concepts. Specifically, this assumes that a company will continue to operate. This allows the division of business operational activities into artificial time periods for reporting purposes, as decided by the business owners. Although businesses intend to exist indefinitely, it is helpful to assess their performance and position based on a certain period of time. By doing so, it gives the company timely feedback and helps it make timely decisions.

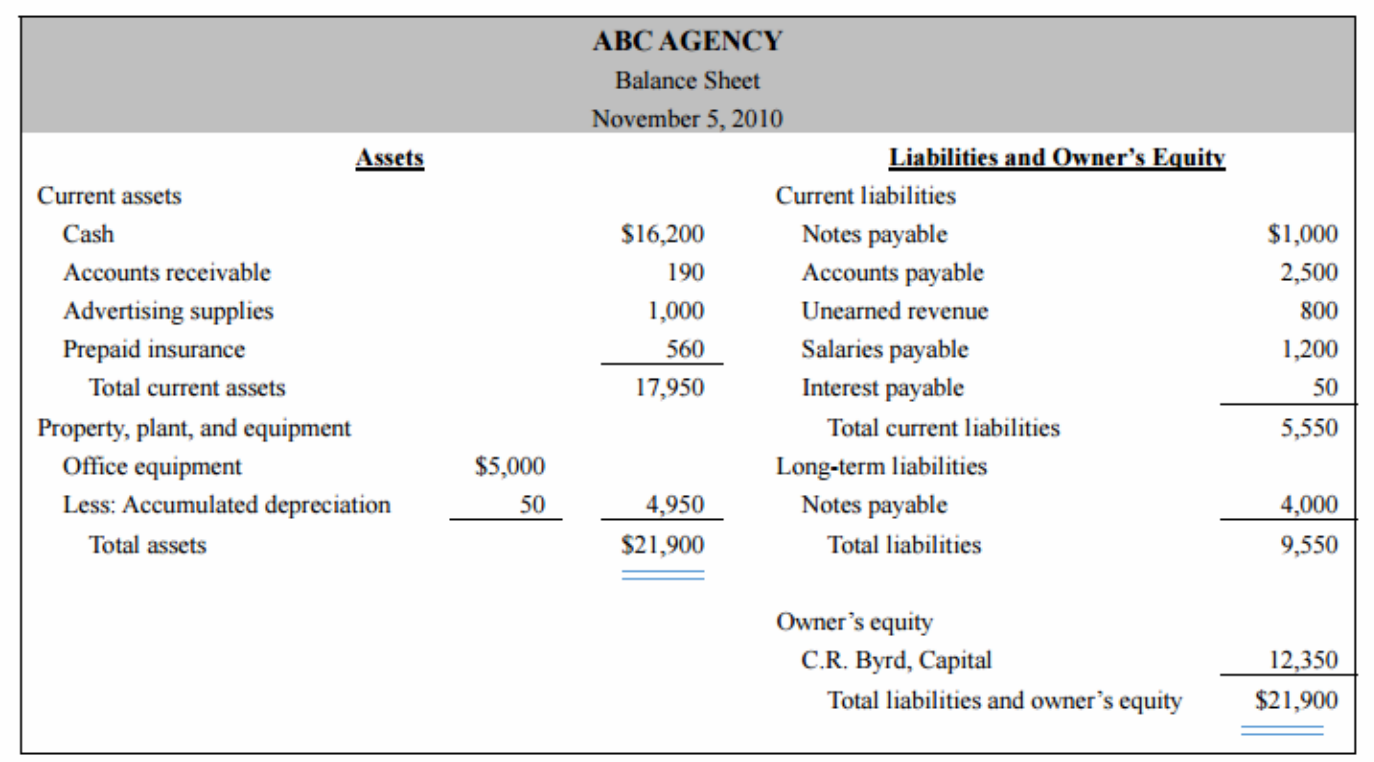

Figure 3. Balance sheet

\footnotetext{
2 Some of the accounting principles and concepts include consistency principle, cost principle, realization principle, the matching principle, objectivity principle, monetary unit principle, reliability principle and time period principle, etc.
} 
The major components in the balance sheet include company's assets, liabilities, and company's equity. Assets (cash, accounts receivable, office equipment), are the resources of the company that benefit its future operations and are converted to cash as required by the cost principle. Examples include land, buildings, receivables, or leaving the asset as cash. Kinserdal (1998) states that accounting works on principles, concepts, and methods. Unit-of-measure assumption is also adopted, and that a company's currency is the appropriate unit of measurement for the business. It also implicitly says that a company's currency is still appropriate even though there would be inflation or deflation that could change the purchasing power of the unit of measure. Liabilities (unearned revenue, salaries payable) are the obligations of parties other than the owners. The balance sheet is an extension of the accounting equation, specifically, Assets $=$ Liabilities + Owner's Equity.

Accounting Data Presentation (Accounting DHP-3) also describes the facts and financial data (as seen in Table 3) that could involve actual plant income, percentage return on capital employed, which includes inventories at standard variable cost, and the replacement value of fixed assets. To enable the company to make financial decisions, information such as direct and indirect expenses are sometimes detailed. For example,

Estimated per unit direct costs of producing the fastening machine were as follows: ... inventory of a three months' supply of raw material ... The length of the production process ... terms of sale were net/30 ... a backlog of orders ... Production and shipments, ... continue at the rate of about 75 units a month ... Monthly indirect expenses were currently running as follows: depreciation ... tooling expenses and experimental manufacture of the prototype ....

Administration expense was expected ... made necessary the purchase of $\$ 19,200$

of special tools. Delivery of these tools ... spent for the replacement of old machinery which appeared to be nearing the end of its useful life. (Hunt \& Williams, 1951: 60)

It appears that accounting professionals use the method of summarizing facts in terms of money transactions or events of a financial character. This harmonizes with Clarke and Robb's observation (2003: 5) that accounting is said to be "the art of recording, classifying and summarizing in a significant manner and in terms of money, transactions, and events which are, in part at least, of a financial character".

\subsection{Accounting DHP-4: Accounting data process}

Accounting DHP-4 (Accounting Data Process) follows Accounting DHP-3 (Accounting Data Presentation). In total, Accounting DHP-4 (Accounting Data Process) takes up 23\% of the contents of the corpus as shown in Table 1. 
Accounting DHP-4 processes the data given in the case. Accounting concerns itself more with reported data when processing the information. For example,

This is helpful because when we eventually review these budgets with top management - the president and executive vice-president - we will have to answer questions about the budgets, and we will know the answers. Second, the review is a way of giving guidance to the plant managers as to whether or not they are in line with what the company needs to make in the way of profits. (Hawkins, 2003:8)

As seen in Table 4, Accounting DHP-4 (Accounting Data Process) includes two generic moves. These moves are Assessing Information and Making Assumptions, and their percentages in Accounting DHP-4 are $72 \%$ and 18\%, respectively.

\begin{tabular}{|l|l|c|}
\hline \multicolumn{2}{|c|}{ Accounting DHP-4: Accounting Data Process } & $\mathbf{\%}$ \\
\hline Move 1 & Assessing Information & 72 \\
\hline Move 2 & Making Assumptions & 18 \\
\hline Total & $\mathbf{1 0 0}$ \\
\hline
\end{tabular}

Table 4. Generic moves found in Accounting DHP-4

Accounting DHP-4's Assessing Information (72\% in Accounting DHP-4) is closely tied to the nature of the disciplinary knowledge involved. Specifically, accounting appraises the data available in the case and the performance of activities over a period of time, such as comparing cost figures. For instance, It cost $£ 300,000$ four years ago, cost us $£ 255,000$ a year ago and bought it for $£ 1,275$ a ton, and you couldn't buy it today for less than $£ 1,450$. Accounting professionals assess information more through accounting principles, such as, monetary unit principle, cost principle, revenue principle, and expenses principle. Principles are essential guidelines when recording and reporting. Thus, accounting works on principles and facts. When assessing information, Accounting cases make regular use of adjectives and comparative adjectives. For instance, at least the inventories get down to a reasonable level when our production volume is low; involved a significant loss of output; some dies were very expensive; this was a fairly typical distribution of the service department's expenses; none of them was more efficient than Forner; he had a good idea of his cost position; will just give us a bigger loss on each model S; More units could have been sold and shipped, but Berks did not wish to risk overextending the company while conditions were so unsettled.

Accounting requires additional reporting when making assessments. Concrete facts and figures are important for comparison. These facts, figures and additional reporting can help various individuals or groups to understand more about the economic activities of their company, and to assess the performance of 
their company. In this way, the information can help decision-makers formulate overall strategies and long-range plans.

Accounting DHP-4's Making Assumptions (18\% in Accounting DHP-4) involves leaning on accounting principles. Permanence of method is a particular principle, which allows the lucidity and comparison of the financial information available to the company. For example,

For instance, he said, what will you do with the machinery? It cost $£ 300,000$ four years ago, but you'd be lucky if you got $£ 50,000$ for it now, even though it's good for another five years or so. And then there's the stock of GHL we bought a year ago. That cost us $£ 255,000$, and at the rate we're using it now, it'll last us another four years or so. We used up about one-fifth of it last year. Dyer's figure of £178,360 for materials probably includes about $£ 51,000$ for GHL. But it'll be tricky stuff to handle if we don't use it up. We bought it for £1,275 a ton, and you couldn't buy it today for less than $£ 1,450$. But you wouldn't have more than $£ 1,100$ a ton left if you sold it, after you'd covered all the handling expenses. (Patel Bhavesh, 2001:261)

Kirkwood (1992) emphasizes that the functions of accounting are primarily to supply information for decision-making, to provide information to interested parties, and to enable them to make appropriate decisions. He further maintains that the important aspect is the communication of the information provided by accounting. Once this information has been communicated, appropriate decisions can be made. This information is generally expressed in monetary terms, for example, It cost $£ 300,000$ four years ago.

Accounting cases involve the use of "if" conditional clauses, Type I (if + Simple Present, will-Future) and Type II (if + Simple Past, would + infinitive), to show the possibility and likelihood that the condition mentioned will be fulfilled. Other types of conditional clauses were not found in this study when making assumptions. The "if" conditional clauses of Type I are used in accounting cases to indicate an action in the future will most likely happen if a certain condition is fulfilled. However, even though it is not certain whether the condition would actually be fulfilled or not, the condition would appear realistic. For instance, But it'll be tricky stuff to handle if we don't use it up; if the change in sales program involves a major plant expense that is out of line with the budget, then the matter is passed up to division top management for a decision.

Accounting cases also involve the use of "if" conditional clauses of Type II to indicate an action that could happen if the current situation were different. However, the situation would not be expected to change, but what would happen would be predicted. For instance, but you'd be lucky if you got $£ 50,000$ for it now; But you wouldn't have more than $£ 1,100$ a ton left if you sold it. 


\subsection{Accounting DHP-5: Accounting closing}

In total, Accounting DHP-5 (Accounting Closing) takes up 2\% of the contents of the corpus as shown in Table 1 . When it comes to the final paragraphs, Accounting DHP-5 is seen to present four generic moves. These moves are Summing Up; Giving Advice and Making Recommendation; Making Prediction; and Talking about Company Policy, and their percentages in Accounting DHP-5 are 44\%, 34\%, 16\%, and 6\%, respectively (see Table 5).

\begin{tabular}{|l|l|c|}
\hline \multicolumn{2}{|c|}{ Accounting DHP-5: Accounting CLOSING } & $\%$ \\
\hline Move 1 & Summing Up & 44 \\
\hline Move 2 & Giving Advice and Making Recommendations & 34 \\
\hline Move 3 & Making Predictions & 16 \\
\hline Move 4 & Talking about Company Policy & 6 \\
\hline Total & $\mathbf{1 0 0}$ \\
\hline
\end{tabular}

Table 5. Generic moves found in Accounting DHP-5

Table 5 reveals that when concluding the final paragraphs, accounting cases involve summing up (44\% in Accounting DHP-5) the financial situation of a specific company. It includes company personnel - finance director, financial figures 75,000 and 100,000, company performance - produced more than 100,000 meters. It presents concluding remarks on a company level. This finding is consistent with the findings in the prior sections (e.g., Background Information). For example,

The finance director prepared estimated costs of Item 345 at various volumes of production (see Exhibit). These estimated costs reflected projected labor and material costs. They were based on past experience except for the estimates of $\underline{75,000}$ and $\underline{100,000}$ meters. The company had produced more than 100,000 meters in each of the last 10 years, and earlier experience was not applicable because of equipment changes and increases in labor productivity. (Anthony, 1956: 380)

Accounting Closing (Accounting DHP-5) also gives advice and makes recommendations (34\% in Accounting DHP-5). Professionals use accounting to give advice and recommendations on recording costs or financial budgetary data. For example,

It is very important that we manage the budget. We have to be continually on guard against its managing us. Sometimes, the plants lose sight of this fact. They continually have to be made conscious of the necessity of having the sales volume to make a profit. And when sales fall off and their programs are reduced, they do not always appear to see the justification for budget cuts - although I suspect they see 
more justification for these cuts than they will admit. It is this human side of the budget to which we have to pay more attention in the future.(Hawkins, 2003:19)

Closing in accounting cases involves predicting what will happen in the future (16\% in Accounting DHP-5) because of knowledge about the financial data analyses. Since the main function of accounting is "to provide quantitative information" (Horngren, Foster, \& Datar, 1997: 2) and "to report the results to decision makers" (Horngren, Harrison, \& Robinson, 1994: 2), predictions are also called for on their part. These predictions are made by senior managers of the company, such as the marketing and production managers. One should note how the first person pronoun is used (Frankly, I doubt), which indicates personal opinions when making predictions in accounting. For example,

Perhaps in the future we can avoid or cut back some of the budget preparation steps and start putting together our sales budget later than May 15. However, $\underline{I}$ doubt if we will change the basic philosophy. Frankly, I doubt if the line managers would want any major change in the system; they are very jealous of the management prerogatives the system gives them. (Hawkins, 2003:19)

Closing in accounting cases involves talking about the company policy (6\% in Accounting DHP-5) in place to control expenses. For example,

... top management felt that both AM Marketing and the three manufacturing divisions carried excessive inventories most of the year. The controller said, Thank goodness we have a generous Christmas vacation policy here; at least the inventories get down to a reasonable level at year-end when our production volume is low because of employee holiday vacations. (Anthony, Hawkins \& Merchant, 2011:700)

As seen from the example - a generous Christmas vacation policy, the emphasis is clearly on the policy of an individual company, highlighting Accounting focuses on the situation of a specific company.

\section{PEDAGOGICAL IMPLICATIONS}

As far as the pedagogical implications are concerned, the findings indicate that there are some fundamental and pedagogical imperatives which may affect the teaching and learning of the accounting discourse. Although teachers of Accounting may already be aware of these imperatives, there is a need to make such knowledge more explicit, in order to help their students understand the discursive demands of Accounting. For example, the use of methods of summarizing facts in terms of money transactions or events of a financial character, in order to point out where the financial problem lies. On the one hand, students need to be aware that 
Accounting requires recording and classifying information involving figures, monetary terms, and calculations. On the other hand, they also need to know how to apply them to the situation given in a case. For example, they must appreciate that financial statements and figures are actually the presentation of data analyses and that these, in turn, are used to interpret the results, to predict the future and to make financial decisions. In view of the fact that Accounting must describe and interpret the texts and the financial information in monetary terms, the higherorder skills of relating text to information systems (of recording, measuring, and documenting data) are required. Accounting is, therefore, not only the language of business; it is also the language of financial decisions. This essential information thus provides the basis not only for the discursive hierarchical patterning but also for the functions, values, and even syntactic realizations in Accounting.

Having accelerated beyond the linguistic skills and knowledge required to perform competencies in a target situation, ESP has become a tool in facilitating success in professional life, and ESP teaching needs to consider "not just what learners want to be able to do in a language but also who they want to become through language" (Belcher \& Lukkarila, 2011: 89, original emphasis). Johns (2011) also points out that genre pedagogies should help students see texts as "both temporarily structured and evolving", so they can "draw from prior knowledge of texts but be open to the demands of a new situation or assignment" (p. 64). Hyland (2013) maintains that conscious-raising method promotes sensitivity and autonomy among students because the method often requires students to analyze texts from their own disciplines and explore multiple features including textual patterns, rhetorical functions, and expectations from the discipline. To raise students' awareness, this paper would suggest using direct teaching by adopting the model of discursive hierarchical patterning of accounting cases (Accounting DHP) to teach the characteristics of accounting discourse. It is thus hoped that this study will serve to sensitize teachers to the need to alert students to the specific demands of Accounting. If students think about the overall discursive hierarchical patterning in accounting cases and if they see the specific information required, they will find it easier to attune to the nature of disciplinary discourse, in this instance, accounting. With the knowledge of this discursive hierarchical patterning of accounting cases, students will consider the major functional components in Accounting. This, in turn, helps students transform disciplinary knowledge and discourse conventions into meaningful dialogues with the evolving knowledge in the discipline, as well as helps them attain greater professionalism while pursuing their academic goals.

\section{CONCLUSION}

The discursive patterns in the proposed discursive hierarchical patterning in accounting cases are intended to represent the ways of integrating accounting 
content and the language for the content. These patterns, to a certain extent, may be attributed to the intrinsic nature of the discipline. For example, Accounting is the process of collecting, classifying, recording, reporting, analyzing, and interpreting financial data to meet the information requirement of different interests, or users, concerned with the operation of a business. Accounting is there to supply information to individual companies to aid them in their decisionmaking, as well as to help users of accounting information.

In summary, this paper examines the genre of accounting cases in academic contexts and has proposed a discursive hierarchical patterning of cases in Accounting with the view to providing insight into the need for more than a general literacy in the use of language. The discourse of accounting cases looks at the financial information about a specific company. For instance, Accounting DHP-1 (Background Information) gives the background information about a specific company, people involved, and the exact time of the financial periods. Accounting DHP-2 (Specific Problem and/or Specific Situation) identifies financial issues involved, and looks at a specific problem or situation facing a company. The problem is identified and pointed out directly in the form of a narrative by people involved in the company. In Accounting DHP-3 (Data Presentation), data is presented through financial statements and figures. There is also the need for higher-order skills of linking financial information to texts as well as having to make assessments and assumptions. In Accounting DHP-4 (Data Process), assessments and assumptions are made through accounting principles, and comparisons of concrete facts and figures. When making assumptions, students need to know how to use "if"conditional clauses. Accounting DHP-5 (Closing) presents concluding remarks on a company level, which could involve summing up the financial situation of a specific company; giving advice and making recommendations as well as talking about the policies of the company. This particular kind of information solicited in accounting is very specific and deals more with meeting the specific needs of the business concerned. These conceptual elements thus contribute, to a large extent, to the discursive hierarchical patterning of the accounting cases. This body of knowledge cannot be gained from the mere reading of cases, but must be part of a concerted effort by teachers at the outset to instill these concepts in the minds of their students, helping students recognize that there is such information as discursive hierarchical patterning in accounting cases on a cognitive level. 


\section{References}

Anthony, R. N., Reece, J. S., \& Hertenstein, J. H. (1994). Accounting: Text and cases. Chicago, IL: Irwin.

Atkins, S., \& Harvey, K. (2010). How to use corpus linguistics in the study of health communication. In A. O'Keeffee, \& M. McCarthy (Eds.), The Routledge handbook of corpus linguistics (pp. 605-619). London: Routledge.

Batty, J. (1986). Management accountancy: Including financial management and control. Plymouth: MacDonald and Evans.

Behnam, B., \& Nikoukhesal, A. (2017). A constrastive study of move structure in the introduction of section of physical versus social sciences research articles in English. The Asian ESP Journal, 13(2), 180-211.

Belcher, D., \& Lukkarila, L. (2011). Identity in ESP context. In D. Belcher, A. Johns, \& B. Paltridge (Eds.), New directions for English for specific purposes research (pp. 73-93). Ann Arbor, MI: University of Michigan Press.

Bhatia, V. K. (1993). Analysing genre: Language use in professional settings. London: Longman.

Bhatia, V. K. (1999). Disciplinary variation in business English. In M. Hewings, \& C. Nickerson (Eds.), Business English: Research into practice (pp. 129-143). Harlow, Essex: Pearson Education Ltd.

Bhatia, V. K. (2004). Worlds of written discourse: A genre-based view. London: Continuum.

Bhatia, V. K. (2016). Critical genre analysis: Investigating interdiscursive performance in professional practice. London: Routledge.

Bhatia, V. K., Jones, R. H., Bremner, S., \& Peirson-Smith, A. (2013). Interdiscursive collaboration in public relations contexts. Ibérica, 25, 127-146.

Bhatia, V. K., Langton, N. M., \& Lung, J. (2004). Legal discourse: Opportunities and threats for corpus linguistics. In U. Connor, \& T. A. Upton (Eds.), Discourse in the professions: Perspectives from corpus linguistics (pp. 203-231). Amsterdam: John Benjamins.

Bhatia, V. K., \& Lung, J. (2012). Analysing international commercial arbitration awards as genre. In V. K. Bhatia, G. Garzone, \& C. Degano (Eds.), Arbitration awards: Generic features and textual realisations (pp. 23-46). Newcastle upon Tyne: Cambridge Scholars Publishing.

Bitchener, J. (2010). Writing an applied linguistics thesis. New York: Palgrave Macmillan.

Candlin, C. N., \& Hyland, K. (Eds.) (2000). Writing: Texts, processes and practices. London, UK: Longman.

Clarke, B., \& Robb, A. (2003). Accounting information for action. Auckland: Longman.

Flowerdew, J., \& Peacock, M. (2001). Issues in EAP: A preliminary perspective. In J. Flowerdew, \& M. Peacock (Eds.), Research perspectives on English for academic purposes (pp. 8-24). Cambridge, UK: Cambridge University Press.

Fryer, D. L. (2012). Analysis of the generic discourse features of the English-language medical research article: A systemic-functional approach. Functions of Language, 19(1), 5-37.

Gil-Salom, L., \& Soler-Monreal, C. (2014). Writer's positioning in literature reviews in English and Spanish computing doctoral theses. Journal of English for Academic Purposes, 16, 23-39. https://doi.org/10.1016/j.jeap.2014.08.002

Hao, J. (2015). Construing biology: An ideational perspective (Unpublished doctoral dissertation). University of Sydney, Sydney, Australia. 
Holmes, R. (1997). Genre analysis, and the social science: An investigation of the structure of research article discussion sections in three disciplines. English for Specific Purposes, 16(4), 321-337.

Horngren, C. T., Foster, G., \& Datar, S. M. (1997). Cost accounting: A managerial emphasis. Upper Saddle River, N.J.: Prentice Hall.

Horngren, C. T., Harrison, W. T., \& Robinson, M. A (1994). Principles of financial and management accounting: A corporate approach. Englewood Cliffs, N.J.: Prentice Hall.

Hyland, K. (2000). Disciplinary discourses: Social interactions in academic writing. Harlow, Essex: Longman Pearson Education.

Hyland, K. (2007). Genre pedagogy: Language, literacy and L2 writing instruction. Journal of Second Language Writing, 16, 148-164.

Hyland, K. (2008). Writing theories and writing pedagogies. Indonesian Journal of English Language Teaching, 4(2), 91-110.

Hyland, K. (2009). Writing in the discipline: Research evidence for specificity. Taiwan International ESP Journal, 1, 5-22.

Hyland, K. (2013). ESP and writing. In B. Paltridge, \& S. Starfield (Eds.), The handbook of English for specific purposes (pp. 95-113). Oxford: Wiley-Blackwell.

Johns, A. M. (2011). The future of genre in L2 writing: Fundamental, but contested, instructional decisions. Journal of Second Language Writing, 20(1), 56-58.

Kinserdal, A. (1998). Financial accounting: An international perspective. London: Financial Times/Pitman Publishing.

Kirkwood, L. (1992). Accounting: An introductory perspective. Melbourne, Australia: Longman.

Kwan, B. S. C., Chan, H., \& Lam, C. (2012). Evaluating prior scholarship in literature reviews of research articles: A comparative study of practices in two research paradigms. English for Specific Purposes, 31(3), 188-201.

Lee, I. (2012). Genre-based teaching and assessment in secondary English classrooms. English Teaching: Practice and Critique, 11(4), 120-136.

Lung, J. (2008). Discursive hierarchical patterning in law and management cases. English for Specific Purposes, 27(4), 424-441.

Lung, J. (2011). Discursive hierarchical patterning in economics cases. English for Specific Purposes, 30(2), 138-149.

Lung, J. (2014). A blended needs analysis: Critical genre analysis and needs analysis of language and communication for professional purposes. In V. K. Bhatia, \& S. Bremner (Eds.), The Routledge handbook of language and professional communication (pp. 257-273). London: Routledge.

Lung, J. (2017). Interdiscursivity in public relations communication: Appropriation of genre and genre resources. HERMES - Journal of Language and Communication in Business, 27(54), 21-33.

McQuade, R. J. (1993). Cases in financial accounting and reporting. New York, NY: McGrawHill.

Paltridge, B. (2001). Linguistic research and EAP pedagogy. In J. Flowerdew, \& M. Peacock (Eds.), Research perspectives on English for academic purposes (pp. 8-24). Cambridge, UK: Cambridge University Press.

Swales, J. M. (1990). Genre analysis: English in academic and research settings. New York: Cambridge University Press. 
Swales, J. M. (2004). Research genres: Explorations and applications. Cambridge: Cambridge University Press.

Tardy, C. M. (2011). The history and future of genre in second language writing. Journal of Second Language Writing, 20(1), 1-5.

JANE LUNG has been working closely with language specialists, subject specialists, LSP practitioners and language teachers in a number of research projects. She has interests in discourse analysis, critical genre analysis, corpus linguistics and professional communication including legal, business, advertising and other promotional genres, as well as language teaching and learning. Projects she has been involved include Analysing Genre-bending in Corporate Disclosure Documents, and International Arbitration Practice: A Discourse Analytical Study in which more than 20 international research teams participated. She is an Associate Professor at Macao Polytechnic Institute.

\section{Appendix 1}

List of accounting textbooks used as sources of the cases

Allen, B. R. (2005). Cases in management accounting and control systems. Upper Saddle River, NJ: Pearson Prentice Hall.

Anthony, R. N. (1956). Management accounting. Homewood, Ill.: R. D. Irwin.

Anthony, R. N., Hawkins, D. F., \& Merchant, K. A. (2011). Accounting: Text and cases. New York: Mc Graw-Hill Education.

Anthony, R. N., Reece, J. S., \& Hertenstein, J. H. (1994). Accounting: Text and cases. Chicago, IL: Irwin.

Barret, M. E., \& Bruns, W. J. (1996). Case problems in management accounting. Homewood, Ill. : R.D. Irwin.

Batty, J. (1986). Management accountancy: Including financial management and control. Plymouth: MacDonald and Evans.

Black, H. A. (1967). A/S Dansk Minox, Copenhagen. Switzerland: IMEDE (International Management Development Institute).

Brewer, P. C., Garrison, R. H., \& Noreen, E. W. (2016). Introduction to managerial accounting. New York, NY: McGraw-Hill Education.

Bruns, W. J., Jr. (2005). "Lille Tissages, S.A." Harvard Business School Case 198-005.

Clarke, B., \& Robb, A. (2003). Accounting information for action. Auckland: Longman.

Edmonds, T. P., Edmonds, C. T., McNair, F. M., \& Olds, P. R. (2016). Fundamental financial accounting concepts. New York, NY: McGraw-Hill Education.

Fischer, P. M., Tayler, W., \& Cheng, R. H. (2016). Advanced accounting. Boston, MA: Cengage Learning.

Harrison, W. T., Horngren, C. T., \& Thomas, C. W. (2015). Financial accounting. Boston: Pearson.

Hawkins, D. F. \& Lane, D. (2013). "Sino-Forest (A)." Harvard Business School Case 112-004.

Hawkins, D. F. (2003). "Empire Glass Company (A)." Harvard Business School Case 109-043.

Hawkins, D. F. (2012). "Sino-Forest (B)." Harvard Business School Supplement 112-066.

Hawkins, D. F. (2012). "Sino-Forest (C)." Harvard Business School Supplement 112-067.

Hawkins, D. F., Misztal, K. \& Beyersdorfer, D. (2011) "Oriflame S.A. (A)." Harvard Business School Case 111-050.

Henry, J. (1992). Westland. Cambridge: University of Cambridge.

Hilton, R. W., \& Platt, D. E. (2016). Managerial accounting: Creating value in a dynamic business environment. New York, NY: McGraw-Hill Higher Education.

Hilton, R. W., Maher, M., \& Selto, F. H. (2012). Cost management: Strategies for business decisions. Boston: McGraw-Hill Create.

Horngren, C. T., Foster, G., \& Datar, S. M. (1997). Cost accounting: A managerial emphasis. Upper Saddle River, N.J.: Prentice Hall. 
Horngren, C. T., Harrison, W. T., \& Robinson, M. A (1994). Principles of financial and management accounting: A corporate approach. Englewood Cliffs, N.J.: Prentice Hall.

Hoyle, J. B., Schaefer, T. F., \& Doupnik, T. S. (2015). Advanced accounting. New York: McGraw-Hill Education.

Hunt, P. \& Williams, C. M. (1951). Case problems in finance. Chicago, IL: Irwin.

Kieso, D. E., Weygandt, J. J., \& Warfield, T. D. (2016). Intermediate accounting. Hoboken, NJ: Wiley.

Kinserdal, A. (1998). Financial accounting: An international perspective. London: Financial Times/Pitman Publishing.

Kirkwood, L. (1992). Accounting: An introductory perspective. Melbourne, Australia: Longman.

Marshall, D. H., McManus, W. W., \& Viele, D. F. (2014). Accounting: What the numbers mean. London: McGrawHill.

McQuade, R. J. (1993). Cases in financial accounting and reporting. New York, NY: McGraw-Hill.

Meigs, R. F., Williams, J. R., Haka, S. F., \& Bettner, M. S. (1999). Accounting: The basis for business decisions. Boston: Irwin/McGraw-Hill.

Nikolai, L. A., Bazley, J. D., \& Jones, J. P. (2010). Intermediate accounting. Mason, OH: South-Western/Cengage Learning.

Patel Bhavesh, M. (2001). Cost accounting for management decisions. New Delhi: Allied Publisher Ltd.

Williams, J. R., Haka, S. F., Bettner, M. S., \& Carcello, J. V. (2015). Financial accounting. New York, NY: McGrawHill Education. 